\title{
WestVirginiaUniversity.
}

Department of Economics

Working Paper Series

\section{Do New Sports Facilities Attract New Businesses?}

Kaitlyn Harger, Brad Humphreys and Amanda Ross

Working Paper No. 15-32

This paper can be found at the College of Business and Economics Working Paper Series homepage: 


\title{
Do New Sports Facilities Attract New Businesses?
}

\author{
Kaitlyn Harger* \\ Florida Gulf Coast University
}

\author{
Brad R. Humphreys ${ }^{\dagger}$ \\ West Virginia University
}

July 31, 2015

\author{
Amanda Ross ${ }^{\ddagger}$ \\ West Virginia University
}

\begin{abstract}
We examine the impact of new sports facilities on new businesses, an unexplored topic in the literature. We use data from the Dunn and Bradstreet MarketPlace files to examine how new sports facilities affect nearby business activity in terms of the number of new businesses and workers. We find no evidence of increased new businesses openings after the opening of new sports facilities in 13 US cities in the 2000s; employment at new businesses near new facilities is larger than at new businesses elsewhere in the MSA; this increase cannot be linked to businesses in any specific industry.
\end{abstract}

JEL Codes: R13, R58, H71, Z23

Key Words: new sports facility, difference-in-differences model, firm level data

\section{Introduction}

Professional sports teams in North America receive large subsidies for the construction and ongoing operation of the stadiums and arenas these teams play in. Proponents of these subsidies frequently tout tangible economic benefits flowing from the events that take place inside professional sports facilities as a justification for these subsidies. A large body of research investigates the tangible and intangible economic impact of professional sports facilities and teams on local economies and finds little evidence that a new facility or team in a city generates new tangible economic benefits commensurate with the subsidies received. However, much of the existing evidence comes from data on income or employment aggregated to the county or metropolitan statistical area (MSA) level. No previous research examines establishment level data.

Some previous evidence suggests that the opening of a new professional sports facility in a city affects the number and composition of businesses located in nearby neighborhoods. Humphreys

\footnotetext{
*Department of Economics and Finance, Lutgert College of Business, Ft. Myers FL 33965-6565; email: kharger@fgcu.edu

${ }^{\dagger}$ Department of Economics, College of Business and Economics, PO Box 6025, Morgantown WV 26506-6025; email: brhumphreys@mail.wvu.edu; phone: 304-293-7871.

${ }^{\ddagger}$ Department of Economics, College of Business and Economics, PO Box 6025, Morgantown WV 26506-6025; email: Amanda.Ross@mail.wvu.edu.
} 
and Zhou (2015) develop a spatial model of the determination of income, employment, business activity, and housing values in a city. This model predicts that the opening of a new sports facility will cause changes in the location and profitability of service providing firms depending on their proximity to the facility and the nature of the service produced. The model predicts exit and entrance of firms depending on the substitutability of the service produced by the firm with live attendance at sporting events. Coates and Humphreys (2003) analyzed earnings per worker and employment in two-digit SIC code service industries before and after the opening of new sports facilities in 37 MSAs over the period 1969-1996. They reported evidence consistent with changes in the number and composition of businesses in these MSAs following the opening of a new sports facility.

In this paper, we analyze the relationship between the opening of a new sports facility in a city and the number and composition of business establishments near new sports facilities. We use establishment-level data from the Dunn and Bradstreet MarketPlace files, which contain a wealth of information on establishment-level business activity, including the industry, age, location, and number of employees of each establishment, to analyze how the local economy changes after the opening of a new sports facility in a city. We use the opening of new sports facilities in the 2000s as a natural experiment to assess the effect of the presence of a new facility on the number of businesses and the number of people employed at these businesses. Our dataset contains information on 13 new stadiums that opened between 2002 and 2006 in 12 Metropolitan Statistical Areas (MSAs). Using a difference-in-differences estimation approach, we compare business activity in census tracts nearby (within 1, 3, and 5 miles) of each new facility with business activity in tracts elsewhere in the MSA. This is the first analysis in the literature to use establishment-level data to estimate the economic impact of professional sports facilities.

We find no evidence of any effect, positive or negative, of new sports facilities on new businesses around these facilities. We find weak evidence of higher employment at new nearby businesses after the opening of a new sports facility compared to new businesses located farther from the facility. An analysis of industry-level data does not uncover any specific patterns of new business openings or increased new employment at new businesses after the opening of a new sports facility. Opening a new stadium or arena does not appear to generate new business formation in nearby locations.

\section{Sports Facilities and Local Economic Development}

A substantial body of empirical research focuses on documenting the economic impact, or lack thereof, of professional sports teams and facilities in urban areas. This literature contains three main streams: research analyzing the effect of professional sports teams and facilities on local income, earnings, and employment; research analyzing their effect on nearby property values; and research valuing the intangible benefits generated by professional and amateur sports. The existing research focuses on analyzing benefits because the costs can be easily identified. Long (2012) estimated more than $\$ 22$ billion (in 2010 dollars) in direct state and local government subsidies were 
allocated for the construction of new professional sports stadiums and arenas in North America over the period 1990-2010. Since these projects are typically financed with tax exempt bonds, the federal government provides additional indirect subsidies for these projects by forgoing tax revenues on these bonds. Given the size of these subsidies, and the fact that the beneficiaries of these subsidies include billionaire owners of professional sports teams and the millionaire players they employ, documenting the benefits generated by professional sports represents an important line of research.

Unfortunately, evidence supporting the proposition that professional sports generate tangible economic benefits in the local economy is scarce. Coates and Humphreys (2008) survey the literature analyzing the relationship between professional sports facilities and teams and local economic activity and report no evidence that the opening of a new professional sports facility in a city, or attracting a new team to relocate to a city, was associated with any detectable increase in local income, earnings, or employment. One explanation for this lack of a tangible economic impact is the displacement effect. A new facility or team attracts large numbers of local residents who spend their entertainment dollars in or around the facility, and not in other neighborhoods where they used to spend these entertainment dollars. This highlights the importance of documenting changes in new business activity after the opening of a new sports facility in a city.

Mixed evidence exists on the effect of professional sports facilities on nearby residential property values. This research typically analyzes residential property values from a single city, so the results are difficult to generalize to a proposed new facility. A number of different methodologies have been used, including hedonic models, spatial autogressive models, repeat sales models, and difference-indifferences models, which further complicates comparisons across different studies. New professional sports facilities have been found to increase, decrease, and have no effect on nearby residential property values in this literature. Ahlfeldt and Kavetsos (2012) survey this literature.

In terms of the value of intangible benefits like civic pride and sense of community generated by the presence of a professional team in a city, contingent value method (CVM) stated preference research consistently estimates positive willingness to pay for these benefits, but the size of the estimates rarely approaches the size of the subsidies. While local residents clearly value the intangible benefits generated by their local teams, the estimated value of these benefits would support relatively modest subsidies for the construction of new facilities. See Johnson et al. (2012) for a recent survey of this literature.

Cantor and Rosentraub (2012) undertook a case study of the effect of the opening of Petco Park in San Diego, a new facility in our sample, on residents of nearby neighborhoods. Cantor and Rosentraub (2012) showed that census tracts and ZIP codes near this new facility experienced in-migration of young, relatively educated people after the opening of this stadium; residential real estate values also remained stable after the stadium opened. While this evidence suggests that a new sports facility can affect the number and characteristics of local residents, these new residents may or may not work in the area. An analysis of establishment-level data can shed light on the ability of new sports facilities to create new jobs near the facility. 
In this paper, we investigate the effect of a new sports facility opening on the opening of new businesses in nearby neighborhoods. To date, much of the literature focused on relatively aggregated measures of local economic activity, including income and employment data aggregated to the Metropolitan Statistical Area (MSA) or county level. This research exploits variation in these variables across MSAs or counties before and after the opening of a new sports facility to estimate the economic impact of new facilities. Coates and Humphreys (2003) undertook a related study using relatively disaggregated data on local employment in different sectors of the economy. Coates and Humphreys (2003) analyzed variation in MSA-level earnings and employment in specific two-digit SIC code service industries in 37 MSAs with a professional sports team over the period 1969-1996. They found that earnings per employee increased in one sector that contains professional sports teams, Amusements and Recreation, after the opening of a new sports facility in a city, but that earnings per employee and employment decreased in other service sectors, notably Retail establishments and Eating and Drinking establishments, after the facilities opened in a city. These results suggest a change in the composition of businesses around new sports facilities after they open.

Humphreys and Zhou (2015) develop a spatial general equilibrium model of the determination of income, employment, business location, and housing values in cities with new professional sports facilities. The model emphasizes that the large crowds of fans attending professional sporting events generate agglomeration effects in specific areas of cities, leading some firms to co-locate near professional sports facilities and others to exit the market due to reduced demand for their services. The model includes monopolistic competition among local non-traded service providers and predicts that the opening of a new sports facility will lead to changes in the composition of businesses located in specific areas of a city. Service providing firms located some distance from a new facility that produce services that are substitutes for live attendance at sporting events will exit the local market after the opening of a new sports facilities since their revenues decline because of the agglomeration effect of the new sports facility. Service providing firms that produce services that are complements to live attendance at sporting events will enter the local market and co-locate near the new facility to take advantage of the agglomeration effects. The overall effect on local welfare can be negative or positive, depending on the size of the agglomeration effect and the impact on nearby property values. This model provides a theoretical context for the existing empirical literature on the economic impact of professional sports on local income and employment. It also generates empirically testable predictions about the effect of an opening of a new professional sports facility on the number and composition of businesses in areas around these facilities. This model motivates the empirical analysis carried out in this paper. 
Table 1: New Sports Facility Openings in Sample

\begin{tabular}{llllll}
\hline Year & MSA & Teams & League & Facility Name & Date Opened \\
\hline 2002 & Boston & Patriots/Revolution & NFL/MLS & Gillette Stadium & September 9 \\
2002 & Detroit & Lions & NFL & Ford Field & August 24 \\
2002 & Houston & Texans & NFL & Reliant Stadium & August 24 \\
2002 & San Antonio & Spurs & NBA & ATT Center & October 18 \\
2002 & Seattle & Seahawks/Sounders & NFL/MLS & CenturyLink Field & July 28 \\
2003 & Cincinnati & Reds & MLB & Great American Ballpark & March 31 \\
2003 & Houston & Rockets & NBA & Toyota Center & October 6 \\
2003 & Philadelphia & Eagles & NFL & Lincoln Financial Field & August 3 \\
2003 & Phoenix & Coyotes & NHL & Jobing.com Arena & December 26 \\
2004 & Memphis & Grizzlies & NBA & FedEx Forum & September 6 \\
2004 & Philadelphia & Phillies & MLB & Citizens Bank Park & April 3 \\
2004 & San Diego & Padres & MLB & Petco Park & April 8 \\
2005 & Charlotte & Bobcats & NBA & TimeWarner Cable Arena & October 21 \\
\hline
\end{tabular}

\section{Empirical Analysis}

\section{Data Description}

To conduct our analysis, we draw upon three different data sets. First, we created a data set with information on the address and opening date of all new NFL, NBA, MLB and NHL facilities between 2002 and 2005. Data on new sports facility openings comes from Long (2012). Table 1 lists all the cities, teams, facility names, and year the stadium opened for all facilities included in our sample. As shown in Table 1, thirteen new facilities opened during our sample period, with two opening in both Philadelphia and Houston. ${ }^{1}$ Five of these facilities were home to NFL teams, four to NBA teams, three to MLB teams, and one to an NHL team. Although two facilities were home to NFL and MLS teams, we do not include new MLS-only facilities in the sample.

We use data from the Dun and Bradstreet (D\&B) Marketplace files for the second quarter of 2002 and 2006 to determine the number of new firms that opened in each city and the amount of new employment at firms at the census tract level in US cities. ${ }^{2}$ We define a new business as a business that has been open for less than one year. These data are collected quarterly by Dun and Bradstreet and were obtained aggregated to the ZIP code level. We convert the ZIP code level data to year 2000 census tract geography using GIS software. ${ }^{3}$ The D\&B data contains a wealth of information on businesses. This includes detailed information on the industry to which each establishment belongs (based on the establishments 2-digit Standard Industrial Classification

\footnotetext{
${ }^{1}$ Two stadiums opened in 2006, the University of Phoenix Stadium in Phoenix and Busch Stadium III in St. Louis. Given that our data is based on observations from the second quarter of 2006, we do not include these stadiums as neither opened before the beginning of the first quarter of 2006.

${ }^{2}$ The D\&B data includes nearly all establishments apart from part-time schedule-C filers; this includes part-time sole proprietors of small businesses. These data have been used in a number of studies including Rosenthal and Strange (2001, 2003, 2005) and Rosenthal and Ross (2010). Kolko and Neumark (2010) and Kolko (2012) use a panel version of the data, the National Establishment Time-Series (NETS), that was jointly developed by Don Walls and Dun and Bradstreet.

${ }^{3}$ To make such a conversion, we assume that the businesses within a ZIP code are uniformly distributed throughout the area.
} 
Code), the number of employees, how long the business has been in operation, and sales information. Summary statistics for the number of new businesses and employment in both 2002Q2 and 2006Q2 are presented on Table 2 .

Table 2: Summary Statistics - New Census Tract Businesses and Employment

\begin{tabular}{lrr|rr}
\hline & \multicolumn{2}{c}{2002 Q2 } & \multicolumn{2}{c}{2006 Q2 } \\
Variable & Mean & Std Dev & Mean & Std Dev \\
\hline Total New Businesses & 6.98 & 11.42 & 8.19 & 12.00 \\
Total New Employment & 54.74 & 264.30 & 31.89 & 127.08 \\
New Manufacturing Firms & 0.472 & 1.20 & 0.477 & 1.12 \\
New Manufacturing Employment & 13.95 & 153.29 & 5.19 & 47.61 \\
New Wholesale Firms & 0.388 & 0.958 & 0.383 & 0.766 \\
New Wholesale Employment & 2.70 & 14.05 & 1.62 & 7.06 \\
New Retail Firms & 1.46 & 2.18 & 1.39 & 1.88 \\
New Retail Employment & 6.13 & 18.84 & 3.82 & 10.65 \\
New FIRE Firms & 0.516 & 1.19 & 0.845 & 1.40 \\
New FIRE Employment & 5.37 & 80.71 & 3.62 & 31.94 \\
New Services Firms & 2.96 & 4.92 & 3.71 & 5.53 \\
New Services Employment & 18.05 & 61.91 & 14.02 & 86.72 \\
New Eating and Drinking Firms & 0.318 & 0.498 & 0.271 & 0.468 \\
New Eating and Drinking Employment & 1.62 & 5.51 & 0.870 & 3.16 \\
New Hotel Firms & 0.034 & 0.133 & 0.022 & 0.100 \\
New Hotel Employment & 0.441 & 2.726 & 0.215 & 3.74 \\
\hline
\end{tabular}

From Table 2, the average census tract in the sample had about 7 new businesses in 2002 and about 8 new businesses in 2006. Each census tract had about 55 employees at new businesses in 2002 and about 32 employees at new businesses in 2006. In both periods, most of the new businesses and employees were in the retail and services industries.

Finally, we use data from the 2000 Census to control for the observable characteristics of the residents of each census tract. We use a variety of socio-economic variables, including average age, percentage female, education measures, average income, and the unemployment rate, to control for tract-specific attributes that may affect where businesses choose to open. Summary statistics for the 2000 Census data are presented in Table 3.

Most census tracts in the sample have slightly more female residents than males. The average age of residents is 35 and the population of the tracts is mostly white. Note that the white, black, and Hispanic categories are not mutually exclusive; black is a racial identifier and Hispanic is an ethnicity identifier. Average household income in 2000 was about $\$ 69,000$ and the average unemployment rate in these tracts was $6.3 \%$. About half the residents of the average tract had some college or a college degree. Very few residents did not graduate from high school. 
Table 3: Summary Statistics for Census Tract-Level Control Variables, 2000 Census

\begin{tabular}{lrr}
\hline Variable & Mean & Standard Deviation \\
\hline Percent Female & $51.13 \%$ & 0.048 \\
Average Age & 35.55 & 5.24 \\
Percent White & $72.14 \%$ & 0.287 \\
Percent Black & $16.70 \%$ & 0.268 \\
Percent Hispanic & $12.51 \%$ & 0.197 \\
Percent with No HS & $7.51 \%$ & 0.084 \\
Percent with HS Diploma & $28.85 \%$ & 0.107 \\
Percent with Some College & $22.25 \%$ & 0.075 \\
Percent with College Degree & $28.09 \%$ & 0.200 \\
Average Income (000) & 69.20 & 34.52 \\
Unemployment Rate & $6.30 \%$ & 0.175 \\
\hline
\end{tabular}

\section{Empirical Approach}

To determine the effect of the opening of a new stadium on new businesses, we compare outcomes in census tracts that are within one mile, three miles, and five miles of the new facilities with outcomes in tracts within the MSA that are not within the specified distance bands. We include only those MSAs that had a new sports facility open between 2002 and 2006 in the sample. Those cities with teams that opened new stadiums or arenas may be different from cities that did not, and it is likely that some of the characteristics that affect this decision are unobservable. To address this issue, we restrict our sample to those MSAs that had a new sports facility open between 2002 and 2006 .

We investigate the effect of the opening of a new sports facility on the number of new businesses in each census tract in an MSA by estimating a difference-in-differences model which compares the number of businesses open for less than one year, and employment at those new businesses, in nearby tracts to those further from the new facilities before and after the opening of the facility. This difference-in-differences model is

$$
Y_{i j t}=\beta_{1} 1(\text { near })+\beta_{2} 1(\text { post })+\beta_{3} 1(\text { near }) \times 1(\text { post })+\alpha X_{i 2000}+\gamma_{j}+\delta_{M S A}+\varepsilon_{i j t} .
$$

$i$ identifies census tracts, $j$ identifies two-digit SIC code industries for businesses in the sample, and $t$ indicates the year. $y_{i j t}$ reflects new business activity in a given SIC code industry in a given census tract and year, in terms of businesses open less than one year and employment at these businesses. We analyze the effect of new sports facilities on both the number of new establishments and employment at these new establishments in each census tract, since businesses vary in terms of the number of people employed. In addition, note that the unit of observation is the number of new businesses in a given industry, in a given census tract and year. We stratify the data by industry because we expect there to be heterogeneous effects across industries (Rosenthal and Strange, 2001, 2003, 2005; Rosenthal and Ross, 2010). 
1 (near) is an indicator variable that equals one if a specific census tract is within the three alternative distance bands (one mile, three miles, and five miles) of the census tract where a new sports facility opened; 1 (post) is an indicator variable that equals one if the year is 2006 , after the new sports facilities in the sample opened. The different distance bands permit us to examine how any effects of a new sports facility dissipate as distance from the facility increases. The parameter of interest in Equation (1) is $\beta_{3}$, which is the estimated parameter on the interaction term, the difference-in-differences estimator of the effect of opening a new sports facility on business activity in census tracts located near the new facility.

$X_{i 2000}$ is a set of control variables for other socio-economic attributes of census tracts, including percent black, percent Hispanic, average age, average income, education measures, and percent female. We also include industry fixed effects, $\gamma_{j}$, at the two-digit SIC code and MSA fixed effects, $\delta_{M S A}$, to control for any differences across industries, as well as to control for any unobservable differences across the cities in our sample. $\varepsilon_{i j t}$ is an idiosyncratic error term that captures the effects of all other factors on the number of new businesses and employment in a census tract. We assume this random variable has a mean of zero, a constant variance, and is uncorrelated across census tracts and over time. We cluster correct the estimated standard errors at the MSA and SIC Code Industry level.

\section{Results}

We estimate the unknown parameters of Equation (1) to determine the effect of opening a new sports facility on the total number of new firms and the total number of employees working at those firms in the treated census tracts. Results from these regressions are presented in Tables 4 and 5 , respectively. The first column compares those census tracts whose geographic centroid is within one mile of the new sports facility to all other tracts in the MSA, the second column compares all census tracts within three miles, and the final column all census tracts within five miles of the new facility. T-statistics are reported below each parameter estimate.

Again, the parameter estimate of interest is on the interaction term between proximity and post facility opening, labeled "D-D interaction" on Tables 4and 5. From Table 4, the results suggest there is an increase in the number of new businesses in MSAs in the sample in 2006 compared to in 2002 , but no change in the number of new businesses within one, three or five miles of new facilities after their opening. The opening of a new sports facility in these twelve MSAs was not associated with any significant change in new business openings.

The results on Table 4 come from samples with about 1.1 million observations. Our sample contains 7,996 census tracts in 12 MSAs. However, note that the unit of observation is businesses in a given census tract $i$ and in a given 2 Digit SIC Code $j$ in 2002 and 2006, and that our the sample contains 592 Digit SIC codes. Therefore, our sample contains 7, $996 \times 59 \times 12 \times 2$ observations.

The estimated coefficients on the Census tract level control variables are generally as predicted and consistent with those in the literature. New business openings are positively, but weakly, associated with average income in Census tracts and positively associated with more educated 
Table 4: Effect of New Facilities on Number of New Businesses

\begin{tabular}{|c|c|c|c|}
\hline & $\begin{array}{c}(1) \\
\text { Within } 1 \text { mile }\end{array}$ & $\begin{array}{c}(2) \\
\text { Within } 3 \text { miles }\end{array}$ & $\begin{array}{c}(3) \\
\text { Within } 5 \text { miles }\end{array}$ \\
\hline \multirow[t]{2}{*}{ Post opening } & $0.011^{* * *}$ & $0.011^{* * *}$ & $0.011^{* * *}$ \\
\hline & 3.85 & 3.84 & 3.84 \\
\hline \multirow[t]{2}{*}{ Within 1 mi. } & 0.001 & - & - \\
\hline & 0.06 & - & - \\
\hline \multirow[t]{2}{*}{ D-D Interaction } & 0.010 & - & - \\
\hline & 0.38 & - & - \\
\hline \multirow[t]{2}{*}{ Within $3 \mathrm{mi}$} & - & 0.001 & - \\
\hline & - & 0.20 & - \\
\hline \multirow[t]{2}{*}{ D-D interaction } & - & 0.016 & - \\
\hline & - & 1.75 & - \\
\hline \multirow[t]{2}{*}{ Within 5 mi. } & - & - & 0.005 \\
\hline & - & - & 1.21 \\
\hline \multirow[t]{2}{*}{ D-D interaction } & - & - & 0.008 \\
\hline & - & - & 1.29 \\
\hline \multirow{2}{*}{$\%$ female } & $-0.180^{* * *}$ & $-0.180^{* * *}$ & $-0.180^{* * *}$ \\
\hline & -7.62 & -7.64 & -7.63 \\
\hline \multirow[t]{2}{*}{ Average age } & $-0.001^{* * *}$ & $-0.001^{* * *}$ & $-0.001^{* * *}$ \\
\hline & -3.59 & -3.60 & -3.61 \\
\hline \multirow[t]{2}{*}{$\%$ white } & $-0.101^{* * *}$ & $-0.101^{* * *}$ & $-0.101^{* * *}$ \\
\hline & -5.55 & -5.55 & -5.55 \\
\hline \multirow[t]{2}{*}{$\%$ black } & $-0.120^{* * *}$ & $-0.120^{* * *}$ & $-0.120^{* * *}$ \\
\hline & -5.36 & -5.36 & -5.36 \\
\hline \multirow{2}{*}{$\%$ hispanic } & $-0.086^{* * *}$ & $-0.086^{* * *}$ & $-0.086^{* * *}$ \\
\hline & -5.66 & -5.66 & -5.66 \\
\hline \multirow[t]{2}{*}{$\%$ no HS } & $-0.108^{* * *}$ & $-0.107^{* * *}$ & $-0.107^{* * *}$ \\
\hline & -4.20 & -4.16 & -4.16 \\
\hline \multirow[t]{2}{*}{$\%$ HS grad } & 0.001 & 0.001 & 0.001 \\
\hline & 0.05 & 0.09 & 0.09 \\
\hline \multirow[t]{2}{*}{$\%$ some college } & $0.053^{* *}$ & $0.054^{* *}$ & $0.054^{* *}$ \\
\hline & 2.58 & 2.60 & 2.61 \\
\hline \multirow[t]{2}{*}{$\%$ college grad } & 0.004 & 0.004 & 0.004 \\
\hline & 0.26 & 0.29 & 0.30 \\
\hline \multirow[t]{2}{*}{ Average Income } & $0.001^{* * *}$ & $0.001^{* * *}$ & $0.001^{* * *}$ \\
\hline & 8.87 & 8.87 & 8.88 \\
\hline \multirow[t]{2}{*}{ Unemployment Rate } & 0.011 & 0.010 & 0.011 \\
\hline & 1.00 & 0.99 & 1.01 \\
\hline \multirow[t]{2}{*}{$\%$ female head family } & -0.011 & -0.011 & -0.011 \\
\hline & -0.95 & -0.94 & -0.94 \\
\hline Observations & 1179882 & 1179882 & 1179882 \\
\hline
\end{tabular}


residents. New business openings are weakly associated with younger residents in census tracts.

Table 5 shows estimates reflecting the effect of new sports facilities on total employment at new businesses in proximity to new sports facilities using the same proximity measures as in Table 4 . The results on Table 5 provide weak evidence that some economic development takes place in tracts near new sports facilities after they open. The difference-in-differences interaction term is positive and statistically significant for tracts located within three miles or less of a new sports facility. Employment at new businesses in these tracts was higher than at new businesses located farther from the new facilities. This result supports the idea proposed by Coates (2007) that professional sports facilities redistribute economic activity without generating new economic activity. The difference-in-differences parameter for tracts located one mile or less from new sports facilities is not statistically different from zero, which indicates that the new businesses located very near these sports facilities did not employ more workers than other new businesses in the MSA. The difference-in-differences parameter is also not statistically significant for those tracts located five miles or less from the new sports stadium. Overall, this evidence of new job creation is weak because the difference-in-differences parameters are not uniformly statistically different from zero across all three model specifications.

The results for the tract-specific control variables on Table 5 are broadly consistent with those on Table 4. One notable exception is that the parameter estimate on the average income variable is not statistically different from zero in the employment regression models. Income in the census tract affects the number of new businesses, but not the number of workers each new business employs.

The model developed by Humphreys and Zhou (2015) predicts that the effects of a new sports facility on nearby businesses will vary depending on the degree of substitution between the service produced by each business and attendance at live sports events. To assess the extent that the relationship between new sports facilities and new business and employment at new businesses is heterogeneous across industries, we estimate the effect of a new facility on firms in the manufacturing, wholesale, retail, Financial Insurance and Real Estate (FIRE), services, eating and drinking establishments, and hotel industries separately. The estimated standard errors are cluster corrected at the MSA-SIC industry code level.

Table 6 contains results for new business activity and employment within three miles of the stadium. Table 6 shows results for only the proximity, post opening, and interaction variables. Results for the other control variables in Equation (1) are available by request from the authors; they generally resemble those on Tables 4 and 4 . Similar results were obtained for the one and five mile distance bands; these results are also available by request from the authors. Each column on Table 6 represents a separate difference-in-differences model estimated using data from a different industry based on 2-digit SIC classifications. The sample sizes in Table 6 are smaller than those on Tables 4 and 4 because each model reported on Table 6 uses data from a single SIC Code industry.

Looking at the results in Table 6, estimating Equation (1) using 2 Digit SIC code industry level data does not shed much additional light on the nature of the economic development in tracts near new sports facilities after they opened reported on Table 5. None of the difference- 
Table 5: Effect of New Facilities on Number of Employees

\begin{tabular}{|c|c|c|c|}
\hline & $\begin{array}{c}(1) \\
\text { Within } 1 \text { mile }\end{array}$ & $\begin{array}{c}(2) \\
\text { Within } 3 \text { miles }\end{array}$ & $\begin{array}{c}(3) \\
\text { Within } 5 \text { Miles }\end{array}$ \\
\hline Post opening & $\begin{array}{c}-0.262^{\text {*** }} \\
-5.75\end{array}$ & $\begin{array}{c}-0.263^{* * *} \\
-5.74\end{array}$ & $\begin{array}{c}-0.263^{* * *} \\
-5.74\end{array}$ \\
\hline Within $1 \mathrm{mi}$. & $\begin{array}{l}-0.247 \\
-2.24\end{array}$ & - & - \\
\hline D-D interaction & $\begin{array}{c}0.397 \\
1.91\end{array}$ & - & - \\
\hline Within $3 \mathrm{mi}$. & - & $\begin{array}{c}-0.276^{* * *} \\
-3.33\end{array}$ & - \\
\hline D-D interaction & - & $\begin{array}{c}0.216^{* *} \\
2.84\end{array}$ & - \\
\hline Within 5 mi. & - & - & $\begin{array}{c}-0.185^{* *} \\
-2.69\end{array}$ \\
\hline D-D interaction & - & - & $\begin{array}{c}0.138 \\
2.11\end{array}$ \\
\hline$\%$ female & $\begin{array}{c}-2.644^{* * *} \\
-3.76\end{array}$ & $\begin{array}{c}-2.639^{* * *} \\
-3.76\end{array}$ & $\begin{array}{c}-2.641^{* * *} \\
-3.76\end{array}$ \\
\hline Average age & $\begin{array}{c}0.018^{* * *} \\
4.16\end{array}$ & $\begin{array}{c}0.018^{* * *} \\
4.16\end{array}$ & $\begin{array}{c}0.018^{* * *} \\
4.17\end{array}$ \\
\hline$\%$ white & $\begin{array}{c}-1.500^{* * *} \\
-3.34\end{array}$ & $\begin{array}{c}-1.500^{* * *} \\
-3.34\end{array}$ & $\begin{array}{c}-1.499^{* * *} \\
-3.34\end{array}$ \\
\hline$\%$ black & $\begin{array}{c}-1.676^{* * *} \\
-3.55\end{array}$ & $\begin{array}{c}-1.676^{* * *} \\
-3.55\end{array}$ & $\begin{array}{c}-1.675^{* * *} \\
-3.55\end{array}$ \\
\hline$\%$ hispanic & $\begin{array}{c}-0.661^{* *} \\
-2.61\end{array}$ & $\begin{array}{c}-0.661^{* *} \\
-2.61\end{array}$ & $\begin{array}{c}-0.660^{* *} \\
-2.61\end{array}$ \\
\hline$\%$ no HS & $\begin{array}{c}-0.987 \\
-2.16\end{array}$ & $\begin{array}{c}-0.995 \\
-2.18\end{array}$ & $\begin{array}{c}-0.996 \\
-2.18\end{array}$ \\
\hline$\%$ HS grad & $\begin{array}{l}-0.057 \\
-0.16\end{array}$ & $\begin{array}{c}-0.064 \\
-0.19\end{array}$ & $\begin{array}{c}-0.064 \\
-0.18\end{array}$ \\
\hline$\%$ some college & $\begin{array}{c}-0.380 \\
-1.04\end{array}$ & $\begin{array}{l}-0.389 \\
-1.06\end{array}$ & $\begin{array}{c}-0.389 \\
-1.07\end{array}$ \\
\hline$\%$ college grad & $\begin{array}{c}0.385 \\
1.19\end{array}$ & $\begin{array}{c}0.379 \\
1.17\end{array}$ & $\begin{array}{c}0.378 \\
1.17\end{array}$ \\
\hline Average Income & $\begin{array}{c}0.002 \\
1.87\end{array}$ & $\begin{array}{c}0.002 \\
1.87\end{array}$ & $\begin{array}{c}0.002 \\
1.86\end{array}$ \\
\hline Unemployment Rate & $\begin{array}{c}0.833 \\
2.45\end{array}$ & $\begin{array}{c}0.835 \\
2.46\end{array}$ & $\begin{array}{l}0.832 \\
2.45\end{array}$ \\
\hline$\%$ female head family & $\begin{array}{c}0.235 \\
1.36\end{array}$ & $\begin{array}{c}0.234 \\
1.36\end{array}$ & $\begin{array}{c}0.234 \\
1.35\end{array}$ \\
\hline Observations & 1179882 & 1179882 & 1179882 \\
\hline
\end{tabular}


Table 6: Difference-in-Difference Estimates by SIC Code Industry, 3 mile radius

\begin{tabular}{|c|c|c|c|c|c|c|c|}
\hline Variable & Mfg. & Wholesale & Retail & FIRE & Services & Eat/Drink & Hotels \\
\hline & \multicolumn{7}{|c|}{ Number of new businesses within 3 miles of new facility } \\
\hline \multirow[t]{2}{*}{ Within 3 mi. } & 0.001 & -0.019 & 0.010 & 0.007 & -0.017 & 0.079 & -0.008 \\
\hline & 0.01 & -0.70 & 0.50 & 0.48 & -1.09 & 1.05 & -0.49 \\
\hline \multirow[t]{2}{*}{ Post opening } & -0.001 & -0.002 & -0.010 & $0.032^{* * *}$ & $0.030^{* * *}$ & -0.041 & -0.007 \\
\hline & -0.56 & -0.18 & -1.34 & 4.96 & 3.38 & -2.84 & -2.00 \\
\hline \multirow{2}{*}{ D-D interaction } & -0.002 & 0.045 & -0.007 & 0.017 & 0.056 & -0.062 & 0.011 \\
\hline & -0.40 & 1.31 & -0.31 & 0.67 & 2.02 & -0.78 & 0.44 \\
\hline \multirow[t]{2}{*}{ Observations } & 399960 & 39996 & 159984 & 139986 & 279972 & 19998 & 19998 \\
\hline & \multicolumn{7}{|c|}{ Number of new employees within 3 miles of new facility } \\
\hline \multirow[t]{2}{*}{ Within $3 \mathrm{mi}$. } & -0.217 & -0.039 & 0.058 & $-0.305^{* *}$ & -0.368 & 0.845 & 0.082 \\
\hline & -2.07 & -0.10 & 0.44 & -2.98 & -2.51 & 1.00 & 0.31 \\
\hline \multirow[t]{2}{*}{ Post opening } & $-0.254^{* * *}$ & $-0.328^{* *}$ & $-0.206^{* * *}$ & -0.156 & $-0.236^{* *}$ & $-0.612^{* * *}$ & -0.160 \\
\hline & -3.38 & -2.74 & -3.60 & -1.34 & -2.74 & -4.85 & -2.45 \\
\hline \multirow[t]{2}{*}{ D-D interaction } & 0.193 & -0.074 & 0.089 & 0.345 & 0.203 & -0.220 & -0.114 \\
\hline & 1.58 & -0.23 & 0.47 & 1.92 & 1.12 & -0.18 & -0.51 \\
\hline Observations & 399960 & 39996 & 159984 & 139986 & 279972 & 19998 & 19998 \\
\hline
\end{tabular}

in-differences parameters are significantly different from zero at conventional levels. The D-D interaction parameter for new businesses in the services industry is borderline significant, but not significant at the $5 \%$ level.

\section{Conclusions}

In this paper, we analyze the relationship between the opening of a new sports facility in a city and the number, employment, and composition of business establishments near new sports facilities. This is the first paper to use establishment-level data to analyze the impact of professional sports facilities on nearby business activity. To conduct our analysis, we use establishment-level data from the Dunn and Bradstreet MarketPlace files, which contain information on business activity, including the industry and location of each business, combined with information on thirteen new sports facility openings between 2002 and 2006 and census tract level data from the 2000 Census. We use the opening of new sports facilities as a natural experiment to assess the effect of the presence of a new sports facility on the number of businesses, and the number of workers employed at these businesses. We compare business activity in census tracts near the new stadium, specifically those areas within 1,3 , and 5 , miles of the new facilities, with business activity elsewhere in the MSA.

We do not find strong evidence of any effect, positive or negative, of new sports facilities on the number of new businesses located near new facilities after opening. Difference-in-differences model estimates find no evidence that more new businesses located near these sports facilities after they opened compared to other parts of the MSA. We find weak evidence that the opening of these 12 new sports facilities was associated with greater employment at new businesses located near the 
facilities after they opened, but this effect is limited to new businesses located less than three miles from the new facilities. This increased employment cannot be attributed to any specific 2 Digit SIC code industry, which further weakens the direct evidence of tangible economic development associated with the opening of new facilities.

The evidence presented in this paper is consistent with the results in Coates and Humphreys (2003), who reported evidence that wages, but not employment, increased in specific 2 Digit SIC code industries after the opening of new stadiums and arenas in a larger sample of U.S. MSAs. In the context of the model developed by Humphreys and Zhou (2015), the results do not indicate that significant agglomeration effects, in terms of new service producing firms co-locating near new sports facilities, occurred in this sample. Evidence of such agglomeration-related co-location would be found in census tracts located in close proximity to new sports facilities, in this case within one mile of the new facilities.

In terms of justifications for sports-related subsidies and the claims made by proponents of these subsidies, the evidence here adds to the substantial existing body of evidence that professional sports do not generate tangible economic benefits in the local economy. Many proponents of subsidies for the construction of new stadiums and arenas claim that these new facilities will generate new jobs and spur economic development in nearby neighborhoods. While the opening of a new facility may lead to in-migration of new residents into previously declining neighborhoods (Cantor and Rosentraub, 2012), proponents of subsidies for these construction projects often argue that new business activity will take place. One way to assess such claims is to analyze variation in new business locations. This analysis of firm-level data finds no evidence that census tracts near new sports facilities have more new businesses than census tracts located farther from the new facilities in the post-opening period. Some weak evidence of job creation at new businesses exists in this setting.

We analyze the effect of new sports facilities on the opening of new businesses, and on employment at these new businesses. However, the opening of a new sports facility could affect existing businesses without spurring new business development. Future research will focus on how the opening of new sports facilities affects existing nearby business activity. One explanation for the lack of evidence supporting the idea that new businesses are attracted to areas surrounding a new sports facility is that existing firms in service producing industries that are complementary to live attendance at sporting events, such as the eating and drinking industry, may expand their capacity to meet the increased demand generated by a new nearby stadium or arena. We plan to use this data set to assess the possibility that new sports facilities affect new firms and existing firms differently. One drawback to the $\mathrm{D} \& \mathrm{~B}$ data is that it is a repeated cross-section that does not explicitly link existing businesses across years. In future research, we intend to utilize panel data on businesses so that we can track the dynamic effects of these new facilities. This will allow us to assess various mechanisms that could driving our results, such as the exit of existing firms from the area following the opening of a new sports facility. 


\section{References}

Ahlfeldt, G. M. and Kavetsos, G. (2012). Outlook, progress and challenges of stadium evaluation. In Maennig, W. and Zimbalist, A. S., editors, International Handbook on the Economics of Mega Sporting Events, pages 279-294. Edward Elgar Publishing.

Cantor, M. B. and Rosentraub, M. S. (2012). A ballpark and neighborhood change: Economic integration, a recession, and the altered demography of San Diegos Ballpark District after eight years. City, Culture and Society, 3(3):219-226.

Coates, D. (2007). Stadiums and arenas: economic development or economic redistribution? Contemporary Economic Policy, 25(4):565-577.

Coates, D. and Humphreys, B. R. (2003). The effect of professional sports on earnings and employment in the services and retail sectors in U.S. cities. Regional Science and Urban Economics, $33(2): 175-198$.

Coates, D. and Humphreys, B. R. (2008). Do economists reach a conclusion on subsidies for sports franchises, stadiums, and mega-events? Econ Journal Watch, 5(3):294-315.

Humphreys, B. R. and Zhou, L. (2015). Sports Facilities, Agglomeration, and Urban Redevelopment. Regional Science and Urban Economics, forthcoming.

Johnson, B. K., Whitehead, J. C., Mason, D. S., and Walker, G. J. (2012). Willingness to pay for downtown public goods generated by large, sports-anchored development projects: The CVM approach. City, Culture and Society, 3(3):201-208.

Kolko, J. (2012). Broadband and local growth. Journal of Urban Economics, 71(1):100-113.

Kolko, J. and Neumark, D. (2010). Does local business ownership insulate cities from economic shocks? Journal of Urban Economics, 67(1):103-115.

Long, J. (2012). Public-Private Partnerships for Major League Sports Facilities. Routledge.

Rosenthal, S. S. and Ross, A. (2010). Violent crime, entrepreneurship, and cities. Journal of Urban Economics, 67(1):135-149.

Rosenthal, S. S. and Strange, W. C. (2001). The determinants of agglomeration. Journal of Urban Economics, 50(2):191-229.

Rosenthal, S. S. and Strange, W. C. (2003). Geography, industrial organization, and agglomeration. Review of Economics and Statistics, 85(2):377-393.

Rosenthal, S. S. and Strange, W. C. (2005). The geography of entrepreneurship in the New York metropolitan area. Economic Policy Review, December:29-53. 